\title{
Age-related physiological and structural traits of chestnut coppices at the Castelli Romani Park (Italy)
}

\author{
Francesca COVONE*, Loretta GRATANI \\ Dipartimento di Biologia Vegetale, Università degli Studi di Roma “La Sapienza”, piazzale Aldo Moro n 5, 00185 Roma, Italy
}

(Received 15 June 2005; accepted 27 October 2005)

\begin{abstract}
Coppices of Castanea sativa Miller (1, 5, 7, 10, 12, 17, 23, 26, and 30 years old stands) were investigated. Total basal area (BA) ranged from $4.9 \pm 1.9 \mathrm{~m}^{2} \mathrm{ha}^{-1}$ (1 year old stands) to $41.0 \pm 2.3 \mathrm{~m}^{2} \mathrm{ha}^{-1}$ (30 years old stands), and Leaf Area Index (LAI) from $0.18 \pm 0.08 \mathrm{~m}^{2}$ $\mathrm{m}^{-2}$ (1 year old stands) to $5.00 \pm 0.22 \mathrm{~m}^{2} \mathrm{~m}^{-2}$ (12 years old stands). Morphological and physiological leaf traits were analysed in 5 (YC) and 23 years old stands (OC) to point out the functional responses to clearing impact. The results pointed out the high productivity of $C$. sativa in the Park, due to favourable climatic and soil conditions. Significant differences of morpho-physiological leaf traits between YC and OC stands were observed during the last period of the vegetative cycle; it could be due to the higher efficiency in resource use of YC leaves than OC.
\end{abstract}

chestnut coppice / age / LAI / leaf physiology / leaf morphology

Résumé - Effet de l'âge sur la physiologie et la morphologie foliaire des taillis de châtaigner dans le Parc de Castelli Romani (Italie). Des taillis de Castanea sativa Miller (âgés de 1, 5, 7, 10,12, 17, 23, 26, et 30 ans) ont été étudiés. La surface totale de base (BA) variait de 4,9 \pm $1,9 \mathrm{~m}^{2} \mathrm{ha}^{-1}$ (peuplement de 1 an) à $41,0 \pm 2,3 \mathrm{~m}^{2} \mathrm{ha}^{-1}$ (peuplement de $30 \mathrm{ans}$ ), et l'indice de surface foliaire (LAI) de $0,18 \pm 0,08 \mathrm{~m}^{2} \mathrm{~m}^{-2}$ (peuplement de 1 an) à $5,00 \pm 0,22 \mathrm{~m}^{2} \mathrm{~m}^{-2}$ (peuplement de 12 ans). La morphologie et la physiologie de caractéristiques foliaires ont été examinées dans les peuplements âgés de 5 (YC) et 23 ans (OC), de façon à montrer les réponses fonctionnelles à l'impact de la coupe. Les résultats montrent une productivité élevée du châtaigner dans le Parc, à la suite de favorables conditions du climat et du sol. Des différences significatives entre les caractéristiques morpho-physiologiques des feuilles des peuplements YC et OC ont été observées pendant la dernière période de la saison de végétation ; cela pourrait être dû à la plus grande efficacité d'utilisation des ressources dans les feuilles de YC par rapport à celles de $\mathrm{OC}$.

taillis de châtaigner / âge / LAI / physiologie foliaire / morphologie foliaire

\section{INTRODUCTION}

The structure of vegetation, as determined by the spatial arrangement of its elements, is the integrated result of natural selection in response to environmental factors and competitive plant interactions $[8,15,38,55]$. Knowledge of quantitative relationships between stand structure and species composition may contribute to more advanced indirect estimations of stand carbon balance and plant productivity [29, 53, 65]. Forest management determines unavoidable changes in forest structure, interfering with self-regulating processes and productivity, and having considerable influence on forest stability [32, 54, 61]. Since the primary source of structural and physiological variability among managed forest stands is determined by differences in rotation stage (time since harvest) [31], understanding the functional status of a managed forest requires an accurate characterization of the different stage of development.
Sweet chestnut (Castanea sativa Miller) stands are distributed all around the western Mediterranean Basin; they are managed as coppices and they are clear-cutted every 15-25 years, according to the local productivity $[6,12,57]$. Chestnut is a moderate heliophile species and, compared to other temperate species, has rather high photosynthetic rates [11, 16, 44], contributing to its fast growth $[12,13,40]$. New management systems underline the use of longer rotation period with a moderate thinning $[3,7,17]$, allowing the branch biomass to increase progressively, and contributing to the improvement of soil fertility, which has been reduced in the past by short rotation periods [48, 49]. At the present, many chestnut coppices are improperly managed resulting in a heavy and progressive reduction of their ecological and economical value [4]. Thus, knowledge of structural and physiological traits of $C$. sativa is crucial to select the best management option for a sustainable development [2]. Although several reports describe the effect of silvicultural

\footnotetext{
* Corresponding author: francesca.covone@uniroma1.it
} 




Figure 1. Location of the study area.

management on stand structure [3, 17, 19, 62], few papers analyse structural and physiological trait changes of chestnut coppices during its growth [16].

The main objective of this research was to analyse the functional responses of chestnut coppices of different age to clearing impact. The general approach was: (1) to analyse plant structural traits and leaf morphological and physiological traits changes according to age, and (2) to analyse relationships between structural and physiological traits. Moreover, physical-chemical soil analysis was conducted. The results obtained could provide information on the status of this ecosystem, offering recommendations for the best management options.

\section{MATERIALS AND METHODS}

\subsection{Study area and climate}

The study was carried out in chestnut stands of different age, located inside the Castelli Romani Park (Italy, lat from $41^{\circ} 41^{\prime}$ to $41^{\circ}$ $49^{\prime} \mathrm{N}$, long from $12^{\circ} 38^{\prime}$ to $12^{\circ} 50^{\prime}$ E) (Fig. 1). Chestnut stands, generally pure, spread from $300 \mathrm{~m}$ (basins of Nemi and Albano lakes) to $956 \mathrm{~m}$ (Monte delle Faete and Monte Cavo) a.s.l. in the considered area.

The soils were andisols, originated from incoherent, easily weatherable rocks (pyroclastites, volcanic ash); they had a very thick blackish A horizon, soft and porous, high in organic matter, with a considerable water retention capacity, directly overlying the strongly weathered parent material (AC profiles); available soil nutrient content was high, the base saturation was over $50 \%$ and homogeneity between stands fairly good [27].

Climatic data were provided by the Velletri Meteorological Station. Total annual rainfall was of $970 \mathrm{~mm}$, most of it (67\%) distributed during autumn-winter. The mean minimum air temperature of the coldest month (January) was $3.9^{\circ} \mathrm{C}$, the mean maximum air temperature of the hottest month (August) was $28.8^{\circ} \mathrm{C}$ and the mean annual temperature was $15.6^{\circ} \mathrm{C}$ (Tab. I) (mean of the years 2000-2004).
Table I. Monthly and annual mean maximum air temperature $\left(\mathrm{T}_{\max }\right)$, monthly and annual mean minimum air temperatures $\left(\mathrm{T}_{\min }\right)$, monthly and annual mean air temperature $\left(\mathrm{T}_{\mathrm{m}}\right)$ and total monthly and annual rainfall (R) for the period 2000-2004 (Meteorological Station of Velletri, lat $41^{\circ} 41^{\prime} \mathrm{N}$, long $12^{\circ} 50^{\prime} \mathrm{E}$, Rome).

\begin{tabular}{lcccc}
\hline & $\begin{array}{c}\mathrm{T}_{\max } \\
\left({ }^{\circ} \mathrm{C}\right)\end{array}$ & $\begin{array}{c}\mathrm{T}_{\min } \\
\left({ }^{\circ} \mathrm{C}\right)\end{array}$ & $\begin{array}{c}\mathrm{T}_{\mathrm{m}} \\
\left({ }^{\circ} \mathrm{C}\right)\end{array}$ & $\begin{array}{c}\mathrm{R} \\
(\mathrm{mm})\end{array}$ \\
\hline Jan & 10.3 & 3.9 & 7.3 & 101.1 \\
Feb & 11.4 & 4.8 & 7.9 & 69.8 \\
Mar & 14.7 & 7.1 & 10.6 & 66.8 \\
Apr & 16.7 & 8.8 & 12.5 & 89.9 \\
May & 22.7 & 13.9 & 18.0 & 56.5 \\
Jun & 27.3 & 18.0 & 22.5 & 31.4 \\
Jul & 28.0 & 19.1 & 23.5 & 32.8 \\
Aug & 28.8 & 20.3 & 24.4 & 40.2 \\
Sep & 23.8 & 15.6 & 19.3 & 81.2 \\
Oct & 20.7 & 13.5 & 17.5 & 104.6 \\
Nov & 16.6 & 10.3 & 14.9 & 164.7 \\
Dec & 11.8 & 6.3 & 8.9 & 130.6 \\
Annual & 19.4 & 11.8 & 15.6 & 970 \\
\hline
\end{tabular}

\subsection{Measured stand structural traits}

Plant structure measurements were carried out during the period February 2003-June 2004 in even-aged monospecific chestnut (Castanea sativa Miller) coppice stands of different age $(1,5,7,10,12$, $17,23,26$, and 30 years old). These stands were subjected to the same management regime. The length of time rotation ranged around 1824 years, even though coppices aged 30 being quite frequent. During the clear-cut, some trees (standards) were spared to provide seeds for natural regeneration and these were clear-cut every two rotation periods.

Sample areas, $400 \mathrm{~m}^{2}$ each, were established for each stand age (20 per stand age), according to Aber [1], Gratani and Crescente [23], and Newbould [41]. Measurements included stool density (STOd, 
stool ha-1), shoot density (SHOd, ind ha-1), standard density (STAd, ind ha ${ }^{-1}$ ), stem diameter at breast height (DBH, cm), and the dominant shoot height of each stool $(\mathrm{DH}, \mathrm{m})$ in each stands, according to Gallardo et al. [17] and Rubio and Escudero [54]. Total basal area (BA, $\mathrm{m}^{2} \mathrm{ha}^{-1}$ ) was calculated.

Leaf Area Index (LAI, $\mathrm{m}^{2} \mathrm{~m}^{-2}$ ) was measured in each sample area (20 measurements per stand age) by the LAI 2000 Plant Canopy Analyser (LI-COR Inc., USA), according to Brenner et al. [8], Cutini et al. [14] and Welles and Cohen [66]. Measurements were carried out at the time of the maximum LAI according to Scurlock et al. [58] and corresponding to full leaf lamina expansion [21] in the period 1st July1 st September. In each measurement cycle, the reference measurement was carried out in large clearings near each sample area. The belowcanopy measurements ( 8 per sample area) were carried out randomly according to Li-Cor [36]. The fish-eye lens of the instrument was covered by a view cap with a $45^{\circ}$ opening, in order to be sure that the reference measurements were not influenced by the trees surrounding the clearings and by the operator [36]. All measurements were taken at $1 \mathrm{~m}$ above ground and under condition of totally diffuse light, with the sun at or below the horizon to avoid confusing brightly sunlit leaves for gaps [36]. Furthermore, in order to avoid rapid and transient changes in sky conditions between reference and below-canopy readings, cloudless or uniformly overcast days were chosen [14].

\subsection{Soil analysis}

Triplicate soil samples (per sample area) of about $1 \mathrm{~kg}$ were collected in coppices of 5 (young coppice, YC) and 23 years old (old coppice, OC). Soil samples were blended for granulometric analysis, $\mathrm{pH}$, soil organic matter content $(\mathrm{SOM})$, soil total nitrogen content $\left(\mathrm{N}_{\mathrm{t}}\right)$.

All soil samples were collected at least 5 days after the last rainfall (from 09/07/2004 to 13/07/2004), at $-40 \mathrm{~cm}$ depth, using a drill. Soil samples were air dried at room temperature for about 1 month and then passed through $2 \mathrm{~mm}$ sieve [54]; $\mathrm{pH}$ in $\mathrm{H}_{2} \mathrm{O}$ was measured with a glass electrode in a suspension of soil in deionized water; $\mathrm{N}_{\mathrm{t}}$ content (\%) was determined by Kjeldahl method, and SOM content (\%) was determined according to Walkley [64]. Carbon nitrogen ratio (C/N) was calculated.

Soil water content (SWC, \%, ratio of water mass per fresh soil mass) was determined on samples (500 g each) collected in YC and OC on 13/07/2004, 30/08/2004, and 28/09/2004 (simultaneously at physiological measurements), oven-dried at $90^{\circ} \mathrm{C}$ to a constant mass [25].

\subsection{Morphological and anatomical leaf traits}

Morphological and anatomical measurements were carried out in YC and OC, to point out differences between the different ages [16, 35]. Morphological leaf traits were analysed on 50 fully expanded leaves (5 leaves per 10 selected plants), collected from the external portion of the crown, in YC and OC coppices, on 13/07/2004 and 25/ 10/2004. The selected plants consisted of 20-25 (YC) and 2-4 (OC) re-sprouted shoots whose size was similar within and between plants.

The following parameters were measured: projected leaf surface area (excluding petiole) (LSA, $\mathrm{cm}^{2}$ ), obtained by the Image Analysis System (Delta-T Devices, UK); leaf dry mass (LDM, mg), determined drying at $80^{\circ} \mathrm{C}$ to constant mass.

Leaf mass per unit leaf area (LMA, $\mathrm{mg} \mathrm{cm}^{-2}$ ) was calculated by the ratio of leaf dry mass and one-sided leaf area [50]; specific leaf area (SLA, $\mathrm{cm}^{2} \mathrm{~g}^{-1}$ ) by the ratio of one-sided leaf area and leaf dry mass; leaf tissue density (LTD, $\mathrm{mg} \mathrm{cm}^{-3}$ ) by the ratio of LMA and total leaf thickness [67].

Total leaf thickness (LT, $\mu \mathrm{m})$ was measured from 20 fresh leaf sections (from both YC and OC) analysed by light microscopy, using an image analysis system (ARKON, A\&P, I).

\subsection{Physiological leaf traits}

Gas exchange measurements were carried out during the morning (from 9.00 to 12.00 a.m.) in the following days: 20/06/2004, 13/07/ $2004,30 / 07 / 2004,30 / 08 / 2004,28 / 09 / 2004$, and 25/10/2004 on cloudfree days to ensure that maximum daily photosynthetic rates were reached [51]. 20 mature leaves (4 leaves per 5 selected plants) from the external portion of two south facing branches of each plant in YC and OC stands were measured by a ladder, according to Radoglou [47]. Leaves were retained in their natural position during measurements. Net photosynthetic rate $\left(\mathrm{P}_{\mathrm{N}}, \mu \mathrm{mol} \mathrm{CO}_{2} \mathrm{~m}^{-2} \mathrm{~s}^{-1}\right)$, stomatal diffusive conductance to water vapour $\left(\mathrm{g}_{\mathrm{s}}, \mathrm{mmol} \mathrm{H}_{2} \mathrm{O} \mathrm{m}^{-2} \mathrm{~s}^{-1}\right)$, leaf transpiration rate $\left(\mathrm{E}, \mathrm{mmol} \mathrm{H}_{2} \mathrm{O} \mathrm{m}^{-2} \mathrm{~s}^{-1}\right)$, and photosynthetic active radiation (PAR, $\mu$ mol photon $\mathrm{m}^{-2} \mathrm{~s}^{-1}$ ) were measured by an infrared gas analyser Ciras-1 open system (PP Systems, Hitchin, UK), equipped with a $2.5 \mathrm{~cm}^{2}$ leaf chamber (Ciras-1 Parkinson Leaf Cuvettes, Hitchin, $\mathrm{UK}$ ). Instantaneous water use efficiency (WUE, $\mu \mathrm{mol} \mathrm{CO} \mathrm{mmol}^{-1}$ $\mathrm{H}_{2} \mathrm{O}$ ) was calculated as the ratio of $\mathrm{P}_{\mathrm{N}}$ and $\mathrm{E}$ [68].

Predawn and midday leaf water potential $\left(\Psi_{\mathrm{pd}}, \Psi_{\mathrm{md}}, \mathrm{MPa}\right.$, respectively), and relative water content ( $\mathrm{RWC}_{\mathrm{pd}}, \mathrm{RWC}_{\mathrm{md}}, \%$, respectively) measurements were carried out in the following days: 13/07/2004, 30/ 08/2004, and 28/09/2004, in YC and OC stands (10 leaves per each type) in the same position considered for gas exchange. $\Psi$ was measured using a portable pressure chamber (SKPM 1400, Skye Instruments, Llandrindod Wells, UK) with a sheet of wet filter paper inside the chamber to avoid water loss during measurements [37]. RWC was calculated by $100 \times$ (fresh mass - dry mass) / (water saturated mass dry mass) [20]; the sample leaves were enclosed in plastic sheaths immediately before cutting [63].

Air temperature $\left(\mathrm{Te},{ }^{\circ} \mathrm{C}\right)$ was measured by a portable ThermoHygrometer (HD8901, Delta Ohm, I), simultaneously at physiological measurements.

\subsection{Statistics}

All statistical tests were performed using a statistical software package (Statistica, Statsoft Inc., USA). Significant differences among means of the measured traits were determined by analysis of variance (ANOVA) and Tukey test for multiple comparisons. Correlation coefficients were calculated to examine relationships among the measured traits.

\section{RESULTS}

\subsection{Soil analysis}

Differences among YC and OC soil physical characteristics were not significant; on an average the soils of $\mathrm{YC}$ and $\mathrm{OC}$ were characterized by a $35.7 \pm 12.9 \%$ sand, $54.6 \pm 9.0 \%$ silt, and $9.7 \pm 5.8$ clay (Tab. II). SOM and $\mathrm{N}_{\mathrm{t}}$ contents were respectively $67.8 \%$ and $67.7 \%$ significantly $(P<0.05)$ lower in $Y C$ than in OC.

Significant differences were not observed in soil $\mathrm{pH}$ and $\mathrm{C} / \mathrm{N}$ ratio between $\mathrm{YC}$ and $\mathrm{OC}$ stands. On an average $\mathrm{pH}$ was $6.2 \pm$ 0.5 and $\mathrm{C} / \mathrm{N}$ ratio was $10.7 \pm 1.3$.

\subsection{Stand structural traits}

Significant differences of structural traits were measured among the different stand ages $(1,5,7,10,12,17,23,26$, and 30 years old). STOd ranged from $525 \pm 35$ stool ha $^{-1}$ (30 years) to $546 \pm 35$ stool ha ${ }^{-1}$ (1 year); differences among stand ages 
Table II. Soil physical and chemical characteristics in young coppice (YC) and old coppice (OC).

\begin{tabular}{lcc}
\hline & YC & OC \\
\hline Sand (\%) & $35.4 \pm 14.8^{\mathrm{a}}$ & $36.0 \pm 12.9^{\mathrm{a}}$ \\
Clay (\%) & $10.0 \pm 7.1^{\mathrm{a}}$ & $9.4 \pm 5.3^{\mathrm{a}}$ \\
Silt $(\%)$ & $54.6 \pm 9.7^{\mathrm{a}}$ & $54.7 \pm 9.7^{\mathrm{a}}$ \\
$\mathrm{pH}$ & $6.3 \pm 0.7^{\mathrm{a}}$ & $6.1 \pm 0.3^{\mathrm{a}}$ \\
$\mathrm{SOM}(\%)$ & $3.0 \pm 0.9^{\mathrm{a}}$ & $9.3 \pm 4.0^{\mathrm{b}}$ \\
$\mathrm{N}_{\mathrm{t}}(\%)$ & $0.15 \pm 0.05^{\mathrm{a}}$ & $0.45 \pm 0.16^{\mathrm{b}}$ \\
$\mathrm{C} / \mathrm{N}$ & $10.3 \pm 0.9^{\mathrm{a}}$ & $11.1 \pm 1.7^{\mathrm{a}}$ \\
SWC & $20.3 \pm 3.1^{\mathrm{a}}$ & $20.9 \pm 2.5^{\mathrm{a}}$ \\
\hline
\end{tabular}

$\mathrm{SOM}=$ soil organic matter content; $\mathrm{N}_{\mathrm{t}}=$ soil total nitrogen content; $\mathrm{C} / \mathrm{N}$ $=$ carbon nitrogen ratio; $\mathrm{SWC}=$ soil water content (means among the days 13/07/2004, 30/08/2004, and 28/09/2004). Means with the same letter, between YC and OC, are not significantly different (ANOVA, $P<$ $0.05)$. Standard deviation is shown.



Figure 2. Trend of stool density (STOd) and standard density (STAd), in a chronosequence of chestnut coppice. Standard deviation is shown. Each point is the mean of 20 sample plots.

were not significant (Fig. 2). STAd did not differ significantly among the considered stand age $\left(67.8 \pm 23.6\right.$ ind ha $^{-1}$, mean value) (Fig. 2). SHOd was $15825 \pm 763$ ind ha $^{-1}$ in 1 year old stands (Fig. 3), significantly $(P<0.001)$ decreasing $50 \%$ in 7 years old stands and significantly $(P<0.001)$ decreased in the following years, being $7 \%$ of the initial value at the end of the time-rotation (30 years).

Shoot DBH and DH increased linearly with the age (Fig. 3), being $1.0 \pm 0.5 \mathrm{~cm}$ and $1.5 \pm 0.8 \mathrm{~m}$, respectively, in 1 year old stands, and $19.6 \pm 9.1 \mathrm{~cm}$ and $20.5 \pm 1.1 \mathrm{~m}$, respectively, in 30 years old stands.

BA was $4.9 \pm 1.9 \mathrm{~m}^{2} \mathrm{ha}^{-1}$ in 1 year old stands, significantly $(P<0.001)$ increasing till 7 years; it did not changed significantly
Table III. Summary of significant $(P<0.001)$ correlations between LAI and the considered plant traits $(N=180)$.

\begin{tabular}{llc}
\hline$y-x$ & \multicolumn{1}{c}{ Relationship } & $r$ \\
\hline LAI - DBH & $y=-0.0345 x^{2}+0.8225 x+0.1582$ & 0.88 \\
LAI - BA & $y=-0.0053 x^{2}+0.352 x-1.4109$ & 0.94 \\
LAI - SHOd & $y=-5 \mathrm{E}-08 x^{2}+0.0007 x+3.0413$ & 0.93 \\
LAI - DH & $y=-0.0287 x^{2}+0.8104 x-0.9419$ & 0.93 \\
\hline
\end{tabular}

LAI = Leaf Area Index; DBH = stem diameter at breast height; $\mathrm{BA}=$ total basal area; $\mathrm{SHOd}=$ shoot density; $\mathrm{DH}=$ the dominant shoot height of each stool; $r=$ correlation coefficient.



Figure 3. Trend of shoot density (SHOd), stem diameter at breast height (DBH), the dominant shoot height of each stool (DH), total basal area (BA) and Leaf Area Index (LAI) in a chronosequence of chestnut coppice. Standard deviation is shown. Each point is the mean of 20 sample plots.

from 7 to 23 years, and stabilizing close to $40 \mathrm{~m}^{2} \mathrm{ha}^{-1}$ in the oldest stands (26 and 30 years) (Fig. 3 ).

LAI values significantly varied among the considered coppices (Fig. 3): it was the lowest $\left(0.18 \pm 0.08 \mathrm{~m}^{2} \mathrm{~m}^{-2}\right)$ in 1 year old stands, reaching the highest value $\left(5.00 \pm 0.22 \mathrm{~m}^{2} \mathrm{~m}^{-2}\right)$ in 12 years old stands and decreasing in 23 years old stands $\left(3.60 \pm 0.27 \mathrm{~m}^{2} \mathrm{~m}^{-2}\right)$.

The dependence of LAI upon the analysed structural traits was tested by regressing these variables; there were significant $(P<0.001)$ correlations among the considered traits, and the best fit was a polynomial correlation (Tab. III).

\subsection{Morphological and anatomical leaf traits}

The considered leaf traits didn't vary significantly among YC and OC (Fig. 4) in July. On an average C. sativa had $605 \pm$ $152 \mathrm{mg} \mathrm{LDM}, 83.3 \pm 15.4 \mathrm{~cm}^{2} \mathrm{LSA}, 169.4 \pm 18.2 \mu \mathrm{m} \mathrm{LT}, 7.2 \pm$ $1.0 \mathrm{mg} \mathrm{cm}^{-2}$ LMA, $426.3 \pm 35.6 \mathrm{mg} \mathrm{cm}^{-3} \mathrm{LTD}$, and $141.5 \pm$ $22.9 \mathrm{~cm}^{2} \mathrm{~g}^{-1}$ SLA. 




国 $Y C \quad \mathrm{~N} O C$

Figure 4. Morpho-anatomical leaf traits of $C$. sativa in young coppice (YC) and old coppice (OC) on 13/07/2004 and 25/10/2004. LDM = leaf dry mass; $\mathrm{LSA}=$ projected leaf surface area; $\mathrm{LT}=$ total leaf thickness; LMA = leaf mass per unit leaf area; LTD = leaf tissue density; SLA $=$ specific leaf area. Each point is the mean of 50 leaves for morphological leaf traits and of 20 leaves for anatomical leaf traits. Means significantly different are marked with $* * *(P<0.001)$; n.s. not significant. Standard deviation is shown.

The considered leaf traits showed significant $(P<0.001)$ differences at the end of October: YC had 37\%, 24\%, 45\% and $15 \%$ higher LDM, LT, LMA, and LTD, respectively, than OC and $30 \%$ lower SLA.

\subsection{Physiological traits}

Figure 5 shows that $\mathrm{P}_{\mathrm{N}}$ had two peaks during the study period, the first in the middle of July $\left(20.8{ }^{\circ} \mathrm{C}\right.$ mean air temperature) and the second in September $\left(19.5^{\circ} \mathrm{C}\right.$ mean air temperature) in both $\mathrm{YC}$ and $\mathrm{OC}$. $\mathrm{P}_{\mathrm{N}}$ did not differ significantly between YC and OC $\left(18.2 \pm 2.5\right.$ and $15.8 \pm 1.0 \mu \mathrm{mol} \mathrm{m} \mathrm{m}^{-2} \mathrm{~s}^{-1}$, respectively) in July but it was significantly $(P<0.01)$ higher in $\mathrm{YC}\left(19.9 \pm 2.6 \mu \mathrm{mol} \mathrm{m}{ }^{-2} \mathrm{~s}^{-1}\right)$ than in OC $(14.5 \pm 2.3 \mu \mathrm{mol}$ $\left.\mathrm{m}^{-2} \mathrm{~s}^{-1}\right)$ in September.

Low $\mathrm{P}_{\mathrm{N}}$ rates were monitored in $\mathrm{YC}$ at the end of July (14.6 \pm $\left.2.2 \mu \mathrm{mol} \mathrm{m}{ }^{-2} \mathrm{~s}^{-1}\right)$ and in OC in August $\left(10.7 \pm 1.0 \mu \mathrm{mol} \mathrm{m}{ }^{-2}\right.$ $\left.\mathrm{s}^{-1}\right)$; the lowest values were monitored at the end of October in both YC and OC (on an average $6.1 \pm 1.6 \mu \mathrm{mol} \mathrm{m} \mathrm{m}^{-2} \mathrm{~s}^{-1}$ ).

Stomatal diffusive conductance to water vapour $\left(\mathrm{g}_{\mathrm{s}}\right)$ had the same $\mathrm{P}_{\mathrm{N}}$ trend, showing two peaks (Fig. 5), the first in the middle of July $\left(575 \pm 103\right.$ and $554 \pm 132 \mathrm{mmol} \mathrm{m}^{-2} \mathrm{~s}^{-1}$, in YC and OC, difference not significant) and the second in September $\left(471 \pm 67\right.$ and $293 \pm 65 \mathrm{mmol} \mathrm{m}^{-2} \mathrm{~s}^{-1}$ in YC and OC, values significantly different). $\mathrm{g}_{\mathrm{s}}$ decreased $65 \%$ and $34 \%$ (respect the maximum value) in $\mathrm{OC}$ and $\mathrm{YC}$, respectively, in August.

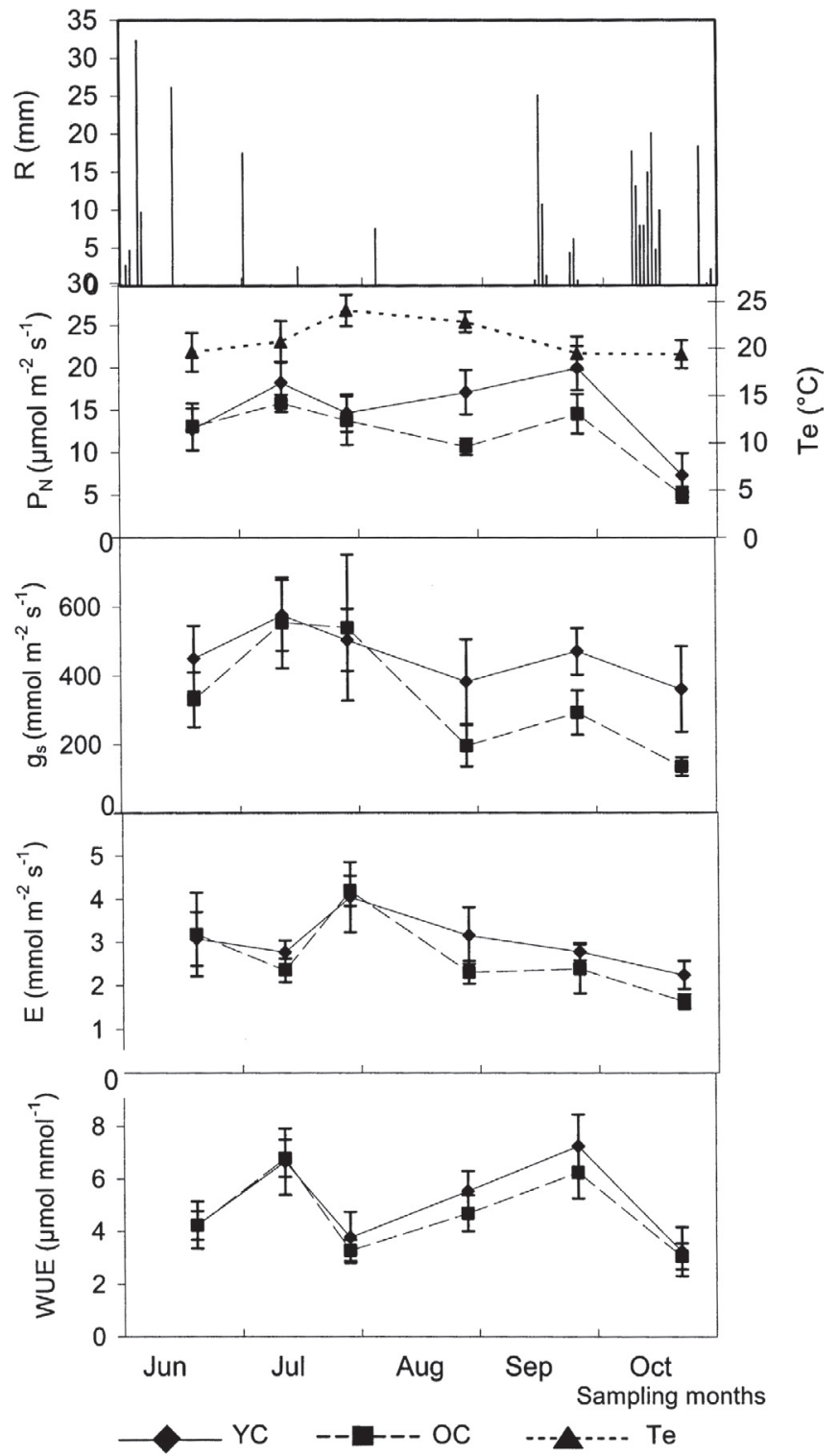

Figure 5. Daily rainfall $(\mathrm{R})$, trend of net photosynthetic rate $\left(\mathrm{P}_{\mathrm{N}}\right)$, stomatal diffusive conductance to water vapour $\left(\mathrm{g}_{\mathrm{s}}\right)$, transpiration rate (E), instantaneous water use efficiency (WUE) of $C$. sativa in young coppice (YC) and old coppice (OC) from the middle of June 2004 to the end of October 2004. Te = air temperature. Standard deviation is shown. Each point is the mean of 20 leaves.

The highest $E$ values $\left(4.04 \pm 0.81\right.$ and $4.19 \pm 0.35 \mathrm{mmol} \mathrm{m}^{-2}$ $\mathrm{s}^{-1}$ in YC and OC, respectively) were monitored at the end of July when air temperature was $24.1{ }^{\circ} \mathrm{C}$ (difference between ages not significant) (Fig. 5).

WUE reached the highest values in the middle of July (6.6 \pm 1.3 and $6.8 \pm 0.7 \mu \mathrm{mol} \mathrm{mmol}^{-1}$ in $\mathrm{YC}$ and $\mathrm{OC}$, respectively) and in September $\left(7.2 \pm 1.2\right.$ and $6.2 \pm 1.0 \mu \mathrm{mol} \mathrm{mmol}^{-1}$ in YC and $\mathrm{OC}$, respectively) (Fig. 5); a reduction (50\% respect to the maximum) was observed at the end of July in YC and OC. Differences between YC and OC stands were not significant. 




Figure 6. Water potential at predawn $\left(\Psi_{\mathrm{pd}}\right)$ and at midday $\left(\Psi_{\mathrm{md}}\right)$, relative water content at predawn $\left(\mathrm{RWC}_{\mathrm{pd}}\right)$ and at midday $\left(\mathrm{RWC}_{\mathrm{md}}\right)$ of C. sativa in young coppice (YC) and old coppice (OC) on 13/07/2004, $30 / 08 / 2004$ and 28/09/2004. Each point is the mean of 10 leaves. Means significantly different are marked with $*(P<0.05), * *(P<$ $0.01)$ and $* * *(P<0.001)$; n.s. not significant. Standard deviation is shown. Values of soil water content in $\mathrm{YC}\left(\mathrm{SWC}_{\mathrm{YC}}\right)$ and $\mathrm{OC}$ $\left(\mathrm{SWC}_{\mathrm{OC}}\right)$ are shown.

Figure 6 shows that the highest $\Psi_{\text {pd }}$ values were monitored in YC and OC stands, at the middle of July (on an average $-0.50 \pm 0.08 \mathrm{MPa}$, difference between $\mathrm{YC}$ and $\mathrm{OC}$ was not significant); in the same period SWC was on an average $22.5 \%$ (in $\mathrm{YC}$ and $\mathrm{OC}$ ).

$\Psi_{\mathrm{pd}}$ and $\Psi_{\mathrm{md}}$ showed a higher decrease in OC (110 and 79\%, $\Psi_{\mathrm{pd}}$ and $\Psi_{\mathrm{md}}$, respectively) than in YC (29\% and 17\%, $\Psi_{\mathrm{pd}}$ and $\Psi_{\mathrm{md}}$, respectively) in August (10.6 mm from 15/07/2004 to 30/ $08 / 2004$ of total rainfall); in the same period SWC significantly $(P<0.01)$ decreased $28 \%$.

$\Psi_{\mathrm{pd}}$ recovered 96 and $81 \%$ in $\mathrm{YC}$ and $\mathrm{OC}$, respectively, and $\Psi_{\mathrm{md}} 23$ and $75 \%$ in YC and OC, respectively, in September; in the same period SWC was on an average $23.1 \%$ (in $\mathrm{YC}$ and OC).

The highest RWC values (> 90\%) were monitored in July in both YC and OC (Fig. 6) (differences between YC and OC were not significant) and $\mathrm{RWC}_{\mathrm{md}}$ was $2 \%$ lower than $\mathrm{RWC}_{\mathrm{pd}}$ (mean value between $\mathrm{YC}$ and $\mathrm{OC}$ ).

A higher RWC decrease was observed in OC (5\% and 29\%, $\mathrm{RWC}_{\mathrm{pd}}$ and $\mathrm{RWC}_{\mathrm{md}}$, respectively) than in $\mathrm{YC}(2 \%$ and $5 \%$, $\mathrm{RWC}_{\mathrm{pd}}$ and $\mathrm{RWC}_{\mathrm{md}}$, respectively) in August. At the end of September $\mathrm{RWC}_{\mathrm{pd}}$ recovered 83 and $88 \%$ in $\mathrm{YC}$ and $\mathrm{OC}$, respectively; there were not significantly differences between $\mathrm{YC}$ and $\mathrm{OC}$ in both $\mathrm{RWC}_{\mathrm{pd}}$ and $\mathrm{RWC}_{\mathrm{md}}$.

\section{DISCUSSION}

The analysed coppices were characterized by low STOd (on an average $536 \pm 7$ stool ha ${ }^{-1}$ ), typical of chestnut coppices derived from the conversion of fruit chestnut, according to Bernetti [5]. The not significant differences in the number of stools and standards per hectare (which were a non-time dependent forestry parameter), between the analysed stands of different age, reinforced our certainty about the homogeneity of the management in the study area.

The high number of shoots developed after the clear-cut from each stool (on an average $30 \pm 11$ shoots per stool) caused a high SHOd in 1 year old coppices. SHOd decreased in the following years owing to the natural mortality of shoots. The highest values of $\mathrm{BA}$ in the oldest coppices were due to high values of DBH (on an average $18.5 \pm 1.6 \mathrm{~cm}$ ), in accordance with the results of Cutini [12].

The high LAI values in 5 years old coppices (20 times higher than in 1 year old coppices) showed the rapid recovery of a closed canopy. The capacity to rebuild the canopy reduced the persistence of other problems associated to this perturbation, mainly leaching.

The correlation analysis (Tab. III) underlined the dependence of LAI on the considered structural traits of the stands. In particular the correlations pointed out the increase of LAI with the increase of DBH, BA, SHOd and DH, until a maximum value falling in turn in the range $10-17$ years. The highest value $\left(5.00 \pm 0.22 \mathrm{~m}^{2} \mathrm{~m}^{-2}\right)$ was measured in 12 years old stands. When DBH, BA, DH increased over $11.9 \mathrm{~cm}, 33.6 \mathrm{~m}^{2} \mathrm{ha}^{-1}$, $14.1 \mathrm{~m}$, respectively, and SHOd decreased over 7000 ind ha ${ }^{-1}$ (in the oldest stands), LAI decreased up to $3.45 \pm 0.18 \mathrm{~m}^{2} \mathrm{~m}^{-2}$. The tendency of the oldest coppices to have a canopy cover lower than younger coppices one could be mainly ascribed to natural evolution of stand structure. It beyond the juvenile phase showed discontinuity and gaps, according to the results of Cutini [13]; this is owed to the low SHOd of the stands (on an average $1350 \pm 205$ ind ha $^{-1}$ ) which caused a low leaf area density. LAI measured in the coppices of different age were in accordance with the results of Gallardo et al. [17], Leonardi et al. [34] and Scurlock et al. [58].

LAI between 10 and 17 years, corresponding to the highest values, might be considered a good estimator of the maximum biomass accumulation [54]. LAI was the most important factor influencing $\mathrm{C}$ assimilation and water loss in plant communities $[21,28,39,60]$ and it might provide an indicator of potential productivity in response to changing factor [23, 25, 26, 42].

The analysis of the physiological traits trend underlined the importance of these traits as indicator of the resources availability $[24,59]$. The optimal $\mathrm{P}_{\mathrm{N}}$ values $\left(17.1 \pm 2.4 \mu \mathrm{mol} \mathrm{m} \mathrm{m}^{-2} \mathrm{~s}^{-1}\right)$ corresponding to favourable air temperature (in the range $19-20^{\circ} \mathrm{C}$ ) for this species were in agreement with those measured by Deweirdt and Carlier [16] and Pontailler et al. [44], and they were higher than those monitored by Gomes-Laranjo et al. [18] and Proietti et al. [46]. The high $\mathrm{P}_{\mathrm{N}}$ rates could be primarily attributed to the favourable climatic conditions and soil physical-chemical characteristics: the water content and SOM never limitant, and the sand-silty and acid soil favour chestnut growth in the Park, according to the results of Bernetti [5], Leonardi et al. [34] and Rubio and Escudero [54]. The higher SOM and 
$\mathrm{N}_{\mathrm{t}}$ contents in $\mathrm{OC}$ than in YC was due to the higher amount of soil litter falling in OC over the years (data not shown), even if the $\mathrm{C} / \mathrm{N}$ ratio value close to 11 in both $\mathrm{YC}$ and $\mathrm{OC}$ pointed out the good state of mineralization and humification processes in both stands.

Moreover, some results underlined significant differences between YC and OC stands, mainly detectable during the last period of the vegetative cycle. $\mathrm{P}_{\mathrm{N}}$ and $\mathrm{g}_{\mathrm{s}}$ were on an average respectively $32 \%$ and $50 \%$ lower in OC than YC stands in the period from August to October, owed to the highest $g_{s}$ decrease $(65 \%)$ in $\mathrm{OC}$ stands, which caused the highest $\mathrm{P}_{\mathrm{N}}$ decrease (32\%).

The relatively high $\mathrm{P}_{\mathrm{N}}$ in $\mathrm{YC}$ was maintained even at low $\Psi$, which showed a reduction at the end of August higher in OC than in YC. RWC paralleled $\Psi$ variability, dropping to $67 \%$ at midday in OC, significantly lower than in $\mathrm{YC}$, even if $\mathrm{g}_{\mathrm{s}}$ was $95 \%$ higher in YC than in OC. These results suggested that in YC C. sativa could partly recover from water loss, maintaining a more favourable ratio between water loss and uptake, resulting in a higher RWC value and higher $\mathrm{P}_{\mathrm{N}}$ rates. Moreover it could also be due to a benefit from the existing root system of this plant species, carbohydrate reserves of the stool and the invigorating effects of decapitation which could cause an initially fast growing of the coppice sprouts, according to the results of Kauppi and Kiviniitty [30] and Rinne et al. [52]. These considerations could also explain the high number of shoots growing from each chestnut stool after the clear-cut and the extremely rapid recovery of a closed canopy.

The not complete recovery of $\Psi$ in September and the lower $\mathrm{P}_{\mathrm{N}}$ values measured in October (2004) were due to the onset of leaf senescence, according to the results of Gratani and Foti [21] and Salleo et al. [56]; the lower $P_{N}$ and $\Psi$ values in OC than in YC might indicate an earlier senescence in OC, which would lead to a worse resource use capacity of $C$. sativa in older coppices, in accordance with the results of Deweirdt and Carlier [16].

The study of variations of leaf morphology in response to stand age and in two different periods of the vegetative cycle reflected the trend of physiological traits. The results were indicative of chestnut adaptability to environmental constraints and of its functional ecology according to Gratani and Bombelli [22], Gratani and Varone [24], and Ponton et al. [45]. In July there were not significant differences between $\mathrm{YC}$ and $\mathrm{OC}$; nevertheless YC leaves collected in October showed a higher LDM, LT, LMA and LTD than in July (2004), improving resistance during the hottest months [10, 22, 24]. The lower LDM, LT, LMA, and LTD in OC than in YC confirmed the early onset of senescence, according to the results of Buchanan et al. [9], Gratani and Varone [24], and Ogaya and Peñuelas [43]. The values of LT and LMA were in accordance with those reported by Lauteri et al. [33] and Proietti et al. [46] for C. sativa.

In conclusion the higher values of $\mathrm{P}_{\mathrm{N}}$ rates measured in both $\mathrm{YC}$ and OC in July than those reported in literature and the optimal $\Psi$ values pointed out the high productivity of $C$. sativa in the Castelli Romani Park, due to the favourable climatic and soil conditions for the species. Although the intensive exploitation of this area, the analysed coppice showed the great capacity to react rapidly and to quickly re-build a homogenous canopy cover. Moreover our results clearly showed the better resource use capacity of $C$. sativa in YC and the higher LAI in
$\mathrm{YC}\left(4.14 \pm 0.45 \mathrm{~m}^{2} \mathrm{~m}^{-2}\right)$ than OC $\left(3.60 \pm 0.27 \mathrm{~m}^{2} \mathrm{~m}^{-2}\right): \mathrm{YC}$ seems to be more productive than OC. Such results are due to neither a different SWC between the two stands nor a different WUE of $C$. sativa; a more stressful condition of $C$. sativa in OC could cause an earlier senescence and so lower Pn rates and $\Psi$ values.

\section{REFERENCES}

[1] Aber J.D., A method for estimated foliage-height profiles in broadleaved forests, J. Ecol. 67 (1979) 35-40.

[2] Amorini E., Analysis of different silvicultural systems in chestnut coppices. Criteria to define a sustainable management, in: Romane F. (Ed.), Second Annual Report of the Cast/Environment Project, C.E.F.E./CNRS, Montpellier, 1996, pp. 71-75.

[3] Amorini E., Bruschini S., Manetti M.C., Alternative silvicultural systems in chestnut (Castanea sativa Mill.) coppice: effects of silvicultural practices on stand structure and tree growth, Ecol. Mediterr. 26 (2000) 155-162.

[4] Amorini E., Chatziphilippidis G., Ciancio O., Di Castri F., Giudici F., Leonardi S., Manetti MC., Nocentini S., Pividori M., Rapp M., Romane F., Sevrin E., Zingg A., Sustainability of chestnut forest ecosystems: Is it possible? Ecol. Mediterr. 26 (2000) 3-14.

[5] Bernetti G., Selvicoltura speciale, UTET, Torino, 1995.

[6] Berrocal M., Gallardo J.F., Cardeñoso J.M., El Castaño, MundiPrensa, Madrid, 1998.

[7] Bourgoise C., Améliorer les taillis de châtaignier, Forêt Entreprise 44 (1987) 8-15.

[8] Brenner A.J., Cueto Romero M., García Haro J., Gilabert M.A., Incoll L.D., Martínez Fernández J., Porter E., Pugnaire F.I., Younis M.T., A comparison of direct and indirect methods for measuring leaf and surface area of individual bushes, Plant Cell Environ. 18 (1995) 1332-1340.

[9] Buchanan B.B., Gruissem W., Jones R.L., Biochemistry and Molecular Biology of Plants, American Society of Plant Physiologists, Rockville, MD, 2000.

[10] Castro-Díez P., Villar-Salvador P., Pérez-Rontomé C., MaestroMartínez M., Montserrat-Martí G., Leaf morphology, leaf chemical composition and stem xylem characteristics in two Pistacia (Anacardiaceae) species along a climatic gradient, Flora 193 (1998) 195-202.

[11] Ceulemans R., Saugier B., Photosynthesis, in: Raghavendra A.S. (Ed.), Physiology of Trees, John Wiley and Sons, New York, 1991, pp. 21-50.

[12] Cutini A., Biomass, litterfall and productivity in chestnut coppices of various age at Monte Amiata (Central Italy), Ecol. Mediterr. 26 (2000) 33-41.

[13] Cutini A., New management options in chestnut coppices: an evaluation on ecological bases, For. Ecol. Manage. 141 (2001) 165174.

[14] Cutini A., Matteucci G., Scarascia Mugnozza G., Estimation of leaf area index with the Li-Cor LAI 2000 in deciduous forests, For. Ecol. Manage. 105 (1998) 55-65.

[15] Degen T., Devillez F., Jacquemart A.L., Gaps promote plant diversity in beech forests (Luzulo-Fagetum), North Vosges, France, Ann. For. Sci. 62 (2005) 429-440.

[16] Deweirdt C., Carlier C., Photosynthèse des feuilles de châtaigniers (Castanea sativa Mill.) mesurée in situ dans des taillis par incorporation de ${ }^{14} \mathrm{CO}_{2}$, Acta Oecol. 9 (1988) 145-160.

[17] Gallardo J.F., Rico M., González M.I., Some ecological aspects of a chestnut coppice located at the Sierra de Gata mountains (Western Spain) and its relationship with a sustainable management, Ecol. Mediterr. 26 (2000) 53-69. 
[18] Gomes-Laranjo J., Araújo-Alves J., Ferreira-Cardoso J., PimentelPereira M., Abreu C.G., Torres-Pereira J., Effect of Chestnut ink disease on photosynthetic performance, J. Phytopathol. 152 (2004) $138-144$.

[19] Gondard H., Romane F., Grandjanny M., Li J., Aronson J., Plant species diversity changes in abandoned chestnut (Castanea sativa) groves in southern France, Biodivers. Conserv. 10 (2001) 189- 207.

[20] Grammatikopoulos G., Mechanism for drought tolerance in two Mediterranean seasonal dimorphic shrubs, Aust. J. Plant Physiol. 26 (1999) 587-593.

[21] Gratani L., Foti I., Estimating forest structure and shade tolerance of the species in a mixed deciduous broad-leaved forest in Abruzzo, Italy, Ann. Bot. Fenn. 35 (1998) 75-83.

[22] Gratani L., Bombelli A., Leaf anatomy, inclination, and gas exchange relationships in evergreen sclerophyllous and drought semideciduous shrub species, Photosynthetica 37 (1999) 573-585.

[23] Gratani L., Crescente M.F., Map-makings of plant biomass and leaf area index for management of protected areas, Aliso 19 (2000) 1-11.

[24] Gratani L., Varone L., Leaf key traits of Erica arborea L., Erica multiflora L. and Rosmarinus officinalis L. co-occurring in the Mediterranean "maquis", Flora 199 (2004) 58-69.

[25] Gratani L., Rossi A., Crescente M.F., Frattaroli A.R., Ecologia dei pascoli di Campo Imperatore (Gran Sasso d'Italia) e carta della biomassa vegetale, Braun-Blanquetia, 16 (1999) 227-247.

[26] Gratani L., Bombelli A., Crescente M.F., Leaf area index (LAI) map of a protected area within the caldera of Vico Lake (Italy), Plant Biosyst. 137 (2003) 141-148.

[27] Guarrera P.M., Boschi e cespuglieti dei Colli Albani (o "Castelli Romani”), in: Ambienti di particolare interesse naturalistico del Lazio. Censimento del patrimonio vegetale del Lazio: quaderno n. 2, Regione Lazio Assessorato alla Cultura, Dipartimento Biologia Vegetale Università "La Sapienza", Roma, Roma, Tipar, 1996, pp. 241-246.

[28] Hoff C., Rambal S., An examination of the interaction between climate, soil and leaf area index in a Quercus ilex ecosystem, Ann. For. Sci. 60 (2003) 153-161.

[29] Ishii H.T., Tanabe S., Hiura T., Exploring the relationships among canopy structure, stand productivity, and biodiversity of temperate forest ecosystems, For. Sci. 50 (2004) 342-355.

[30] Kauppi A., Kiviniitty M., Leaf morphology and photosynthetic rate in birch seedlings and stump sprouts, Can. J. For. Res. 20 (1990) 952-960.

[31] Kowalski A.S., Loustau D., Berbigier P., Manca G., Tedeschi V., Borghetti M., Valentini R., Kolari P., Berninger F., Rannik Ü., Hari P., Rayment M., Mencuccini M., Moncrieff J., Grace J., Paired comparisons of carbon exchange between undisturbed and regenerating stands in four managed forests in Europe, Global Change Biol. 10 (2004) 1-17.

[32] Larsen J.B., Ecological stability of forest and sustainable silviculture, For. Ecol. Manage. 73 (1995) 85-96.

[33] Lauteri M., Scartazza A., Guido M.C., Brugnoli E., Genetic variation in photosynthetic capacity, carbon isotope discrimination and mesophyll conductance in provenances of Castanea sativa adapted to different environments, Funct. Ecol. 11 (1997) 675-683.

[34] Leonardi S., Rapp M., Failla M., Guarnaccia D., Biomasse, productivité et transferts de matière organique dans une séquence altitudinale de peuplements de Castanea sativa Mill de l'Etna, Ann. For. Sci. 53 (1996) 1031-1048.

[35] Leonardi S., Santa Regina I., Rapp M., Gallego H.A., Rico M., Biomass, litterfall and nutrient content in Castanea sativa coppice stands of southern Europe, Ann. For. Sci. 53 (1996) 1071-1081.

[36] Li-Cor, LAI-2000 Plant Canopy Analyzer Operating Manual, Lincoln, NE, USA, 1991.
[37] Lo Gullo M.A., Salleo S., Different strategies of drought resistance in three mediterranean sclerophyllous trees growing in the same environmental conditions, New Phytol. 108 (1988) 267-276.

[38] Lyon J., Gross N.M., Patterns of plant diversity and plant-environmental relationships across three riparian corridors, For. Ecol. Manage. 204 (2005) 267-278.

[39] Morales D., Jiménez M.S., González-Rodriguez A.M., Cermák J., Laurel forests in Tenerife, Canary Islands: I. The site, stand structure and stand leaf area distribution, Trees 11 (1996) 34-40.

[40] Mousseau M., Effects of elevated $\mathrm{CO}_{2}$ on growth, photosynthesis and respiration of sweet chestnut (Castanea sativa Mill.), Vegetatio 104/105 (1993) 413-419.

[41] Newbould P.J., Methods for estimating the primary production of forest, Blackwell Scientific Publications, Oxford, Edinburgh, 1967.

[42] Ni J., Zhang X., Scurlock J.M.O., Synthesis and analysis of biomass and net primary productivity in Chinese forests, Ann. For. Sci. 58 (2001) 351-384.

[43] Ogaya R., Peñuelas J., Comparative seasonal gas exchange and chlorophyll fluorescence of two dominant woody species in a Holm Oak forest, Flora 198 (2003) 132-141.

[44] Pontailler J.Y., Leroux M., Saugier B., Évolution d'un taillis de châtaigniers après coupe : photosynthèse et croissance des rejets, Acta Oecol. 5 (1984) 89-99.

[45] Ponton S., Dupouey J.L., Dreyer E., Leaf morphology as species indicator in seedlings of Quercus robur L. and $Q$. petraea (Matt.) Liebl.: modulation by irradiance and growth flush, Ann. For. Sci. 61 (2004) 73-80.

[46] Proietti P., Palliotti A., Famiani F., Antognozzi E., Ferranti., Andreutti R., Frenguelli G., Influence of leaf position, fruit and light availability on photosynthesis of two chestnut genotypes, Sci. Hortic. 85 (2000) 63-73.

[47] Radoglou K., Environmental control of $\mathrm{CO}_{2}$ assimilation rates and stomatal conductance in five oak species growing under field conditions in Greece, Ann. For. Sci. 53 (1996) 269-278.

[48] Ranger J., Nys C., Biomass and nutrient content of extensively and intensively managed coppice stands, Forestry 69 (1996) 83-102.

[49] Ranger J., Félix C., Bouchon J., Nys C., Ravart M., Dynamique d'incorporation du carbone et des éléments nutritifs dans un taillis simple de châtaignier (Castanea sativa Milller.), Ann. For. Sci. 47 (1990) 413-433.

[50] Reich P.B., Walters M.B., Ellsworth D.S., Leaf life-span in relation to leaf, plant, and stand characteristics among diverse ecosystems, Ecol. Monogr. 62 (1992) 365-392.

[51] Reich P.B., Kloeppel B.D., Ellsworth D.S., Walters M.B., Different photosynthesis-nitrogen relations in deciduous hardwood and evergreen coniferous tree species, Oecologia 104 (1995) 24-30.

[52] Rinne P., Saarelainen A., Junttila O., Growth cessation and bud dormancy in relation to ABA level in seedlings and coppice shoots of Betula pubescens as affected by a short photoperiod, water stress and chilling, Physiol. Plant. 90 (1994) 451-458.

[53] Romane F., Introduction and objectives, in: Romane F. (Ed.), Sustainability of Mediterranean ecosystems. Case study of the chestnut forest, European Commission, Brussels, Ecosystem research report 19, 1995, pp. 1-5.

[54] Rubio A., Escudero A., Clear-cut effects on chestnut forest soils under stressful conditions: lengthening of time-rotation, For. Ecol. Manage. 183 (2003) 195-204.

[55] Sala A., Sabaté S., García C., Tenhunen J.D., Canopy structure within a Quercus ilex forested watershed: variations due to location, phenological development, and water availability, Trees 8 (1994) 254-261.

[56] Salleo S., Nardini A., Lo Gullo M.A., Ghirardelli L.A., Changes in stem and leaf hydraulics preceding leaf shedding in Castanea sativa L., Biol. Plant. 45 (2002) 227-234. 
[57] Santa Regina I., Organic matter distribution and nutrient fluxes within a sweet chestnut (Castanea sativa Mill.) stand of the Sierra de Gata, Spain, Ann. For. Sci. 57 (2000) 691-700.

[58] Scurlock J.M.O., Asner G.P., Gower S.T., Worldwide historical estimates of leaf area index, 1932-2000, ORNL Technical Memorandum ORNL/TM-2001/268, Oak Ridge National Laboratory, Oak Ridge, TE, 2001.

[59] Sellin A., Kupper P., Within-crown variation in leaf conductance of Norway spruce: effects of irradiance, vapour pressure deficit, leaf water status and plant hydraulic constraints, Ann. For. Sci. 61 (2004) 419-429.

[60] Specht R.L., Specht A., Canopy structure in Eucalyptus-dominated communities in Australia along climatic gradients, Acta Oecol. 10 (1989) 191-213.

[61] Swanson F.J., Franklin J.F., New forestry principles from ecosystem analysis of Pacific Northwest forest, Ecol. Appl. 2 (1992) 262274.

[62] Tindall J.R., Gerrath J.A., Melzer M., McKendry K., Husband B.C., Boland G.J., Ecological status of American chestnut (Casta- nea dentata) in its native range in Canada, Can. J. For. Res. 34 (2004) 2554-2563.

[63] Turner N.C., Technique and experimental approaches for measurements of plant water status, Plant Sci. 58 (1981) 339-366.

[64] Walkley A., A critical examination of a rapid method of determining organic carbon in soil-effect of variations in digestion conditions and of inorganic constituents, Soil Sci. 63 (1946) 251-263.

[65] Waring R.H., Estimating forest growth and efficiency in relation to canopy leaf area, Adv. Ecol. Res. 13 (1983) 327-354.

[66] Welles J.M., Cohen S., Canopy structure measurement by gap fraction analysis using commercial instrumentation, J. Exp. Bot. 47 (1996) 1335-1342.

[67] Wright I.J., Westoby M., Leaves at low versus high rainfall: coordination of structure, lifespan and physiology, New Phytol. 155 (2002) 403-416.

[68] Wuenscher J.E., Kozlowski T.T., Relationship of gas-exchange resistance to tree-seedling ecology, Ecology 52 (1971) 1016-1023. 